\title{
暴風雪災害への取り組み \\ Countermeasures in Engineering toward Snowstorm
}

高橋 徹*

Toru TAKAHASHI

1.はじめに

一般には風を伴う雪（風工学的には雪を伴う風かも しれない）は，吹雪と呼ばれるが，災害をもたらすよ うな強風の場合は暴風雪と呼ばれている。気象の分野 ではいったん積もった雪が風で巻き上げられて発生す る事象を地吹雪と呼んで区別しているが，本稿では取 り立てて区別する必要がある場合を除いてこれらを総 称して用い，建築物，道路，送電施設などに影響を及 ぼす暴風雪とそれによって引き起こされる種々の災害 を概観し，それらに対する災害軽減に向けた取り組み を紹介する。

\section{2，暴風雪による災害}

\section{1 視程障害}

強風時の屋外で空気中に含まれる雪の粒子の密度を だんだん高くしていくことを想像してもらいたい。雪 質により様々な様相を示しはするが，ある程度を超え ると，昼間でも数メートル先さえ見えなくなる。これ がホワイトアウトで，いくらライトを付けていても自 動車の運転は非常に危険である。数年前に, 北海道で, 暴風雪のために車を放棄した親子が市街地（郊外では あったが）で遭難した例はまさにこの暴風雪による視 程障害により，自分がどこにいるのかさえわからなく なったことによる悲劇であった。発見された地点は民 家から数十メートルしか離れていなかったという1)。

私自身，故郷（秋田県の内陸部）での登下校時に自
動車が接近しているのに数メートルになるまで気がつ かなかったことが何度かある。日本海沿岸の地吹雪常 襲地帯では，これを逆手にとって「地吹雪ツアー」な どが企画されていたりして, 経験豊かなツアーガイド により安全に実行されることを前提として, 観光資源 にさえなっている。

道路交通を考えると, 視程障害は致命的で, 安全な 車の走行は極めて困難になる。このため, 主要幹線国 道の峠には路面監視カメラが設置され，気象観測も同 時に行っていて, 必要に応じて通行止めの措置を行う などの安全対策が取られている (図 1参照)。

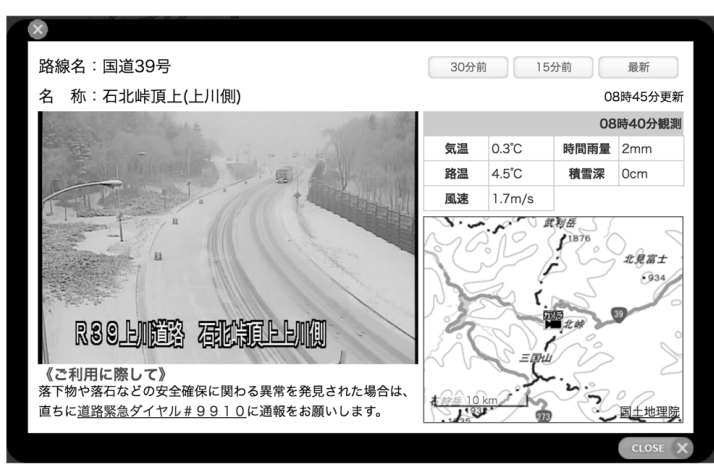

図 1 峠道の路面情報提供例 2)

図 1 からもわかるように, 雪国の峠道では 5 月にも 吹雪となる事もある。地域外からの旅行者にはリアル

* 千葉大学大学院工学研究院 教授・工博

Professor, Graduate School of Engineering, Chiba University, Dr.Eng. 
タイムの情報提供に勝る安全策は無い。このような

ITS (Intelligent Transport Systems) の一例は, 現在, ETC2.0 と連動してカーナビでも情報を得られるよう になり始めており, 今後の安全な道路交通に役立つも のと期待される。

\section{2 吹き溜まり}

a) 道路の吹き溜まり

前節で紹介した親子が車を放棄した最大の理由は, 視程障害もさることながら，車が道路上にできた吹き 溜まりに突っ込んで身動きが取れなくなったことが大 きいと考えられる。事故後の報道では吹き溜まりに突 つ込んだ状態で止まっている自動車が何度も報道され ていた。道路管理者にとっては道路上に吹き溜まりが できることは非常に頭の痛い問題で, 国道では $10 \mathrm{~cm}$

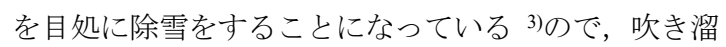
まりができやすいところがあれば, それだけ頻繁に道 路除雪をしなければならないことになる。

この対策として, 道路脇に防雪柵を設けて, 路面上 に吹き溜まりを形成しづらくする方法がとられる。防 雪柵には, 吹きだめ柵, 吹き止め柵, 吹き払い柵の 3 種類がある。吹きだめ柵は道路から少し離れたところ に柵を設けることでその前後に吹き溜まりを形成させ るもの, 吹き止め柵は吹き溜まりをその柵で受け止め, 風下側の吹き溜まりを低減させるもの, 吹き払い柵は 柵を設けることにより通過風速を制御して, 路面を吹 き払い状態に制御するものであり, 結果的に路面位置 での吹き溜まりを低減する効果を期待している。（図 2 参照)
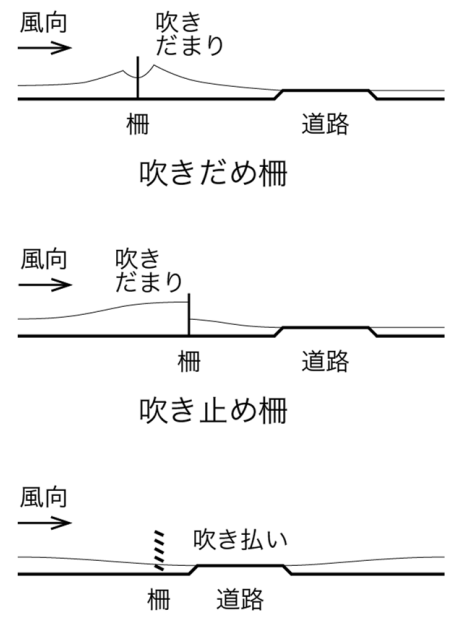

吹き払い柵 b) 鉄道の吹き溜まり

鉄道でも同様の対策が取られており，明治以来，吹 雪防止林として整備されてきた。1893 年に岩手県水沢 から青森間の約 40 箇所に整備されたのがその始まり とされている ${ }^{4) 5)}$ 。近年では，初期に整備された防雪林 が伐採時期に掛かっていて，計画的な更新が吹き溜ま り防止のために欠かせない。（図 3 参照)
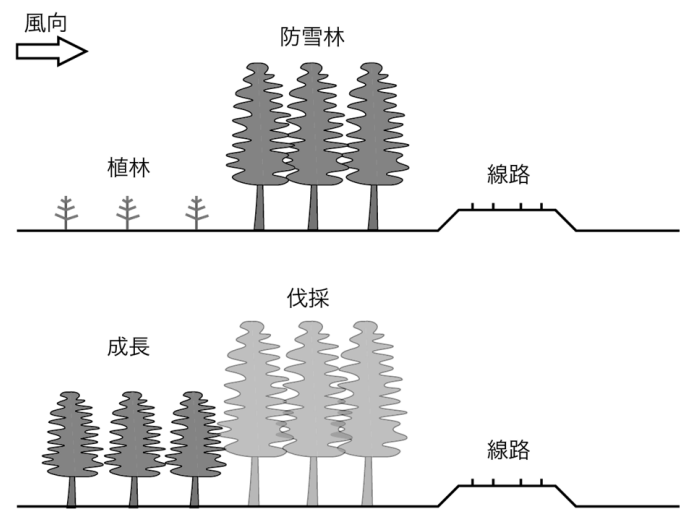

図 3 防雪林の更新概念図

2005 年 12 月に山形県内で発生した特急電車の脱線 転覆事故の遠因の一つとして, 数日来の豪雪（平成 18 年豪雪の前触れ）により，吹き溜まり等が形成され， 1 時間程度の列車の遅延が起きていたことも挙げられ ている。事故そのものは局所的な突風によるものとさ れたので，たとえ防雪林が整備されていたとしても防 ぐことができたかどうかは筆者にはわからない。

c) 建物周りの吹き溜まり

上述のような吹き溜まり現象は，当然のことながら 建物の周りでも発生している6)。市街地で著しい問題 になることは少ないが, 建物の配置をよく考えないと, 立関周りに吹き溜まりが発生し，毎日の除雪の手間が 無視できない違いとなる (図 4 参照)。図 4 の写真が撮 影された日（2014 年 2 月 9 日）は気象庁に依れば千葉 市で $33 \mathrm{~cm}$ の積雪が記録されているが，写真からもわ かるように二階建て住宅の 2 階の屋根では $10 \mathrm{~cm}$ 程度 しか積もっていないところが多い一方で，玄関先には $50 \mathrm{~cm}$ 程度の吹き溜まりが認められる。

図 2 様々な防雪柵 


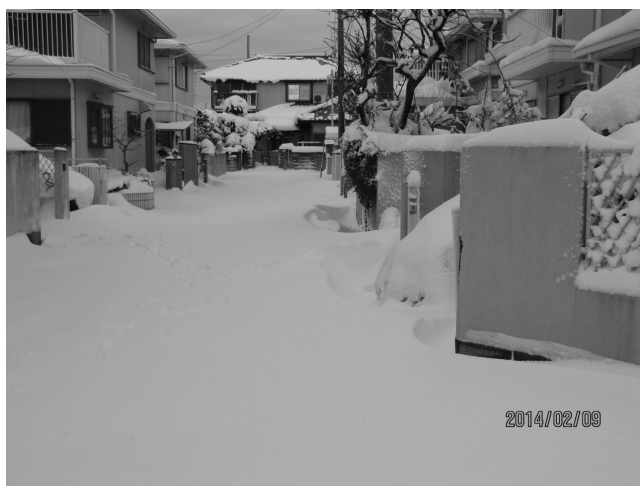

図 4 建物周りの吹き溜まりの例

地吹雪常襲地帯では屋敷林を構えて吹き溜まりに備 える，ということも慣習として行われてきた（図 5 参 照)。屋敷林があるのは，散住の農村のことが多い。集 住の市街地では，住宅同士が比較的密に並ぶことで粗 度を高めて, 風速が低減される方向に作用するので, 極度な暴風雪の問題も低減されるのに比へ，散住集落 の場合は個々の屋敷が季節風の影響に備える必要があ ることから発達したものと考えられる。

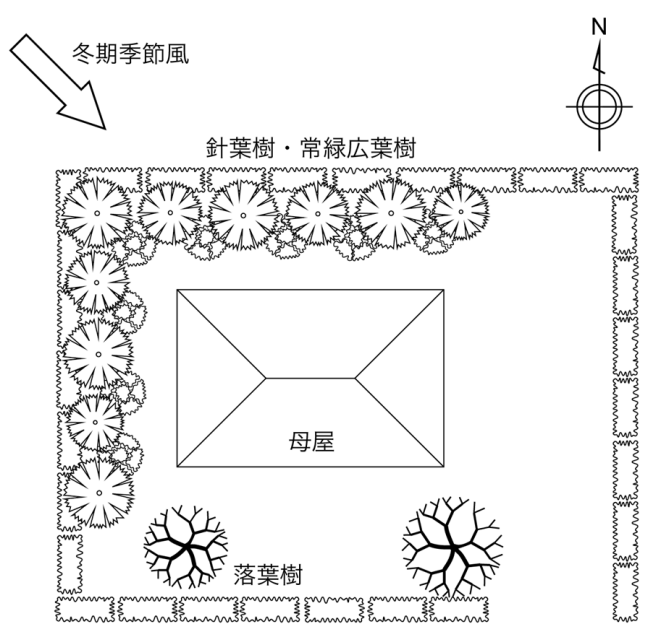

困 5 屋敷林の概念困

\section{d) 屋根上の吹き溜まり}

建物の屋根の上に限って見ても吹き溜まりによる支 障は発生する。典型的な例が暴風雪による屋根雪の偏 分布である。大きな屋根では，吹き払いと再付着が同 じ屋根の上で完結してしまうため，風下側に吹き溜ま りが生じることが指摘されていて，建物の大型化に伴 って今後問題が顕在化する可能性がある (図 6 参照)。

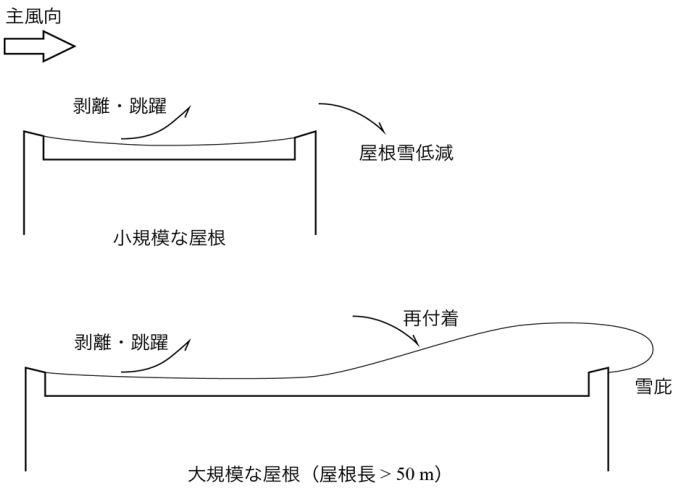

図 6 屋根上の吹き溜まり概念図

日本建築学会の荷重指針7)でも指摘されているよう に，屋根上風速の速いところほど，吹き溜まりの影響 が大きくなる。屋根の上だけなら荷重が増える分を設 計で見込めばよいが，二段屋根の下段の吹き溜まりの 場合，壁部に開口部があると，荷重だけの問題ではな くなってしまう (図 7 参照)。開口部をどう保護する のか，計画的な配慮が必要となる。

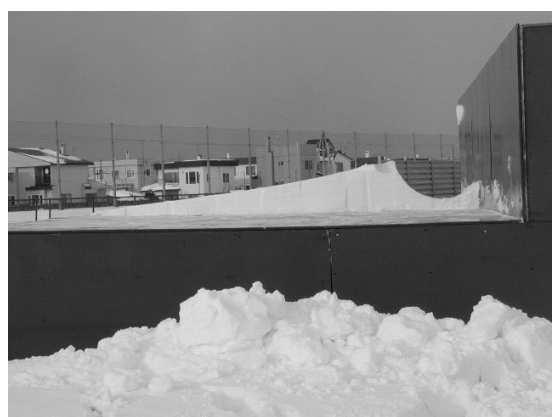

図 7 二段屋根の吹き溜まり例 7)

e) 雪庇，巻き垂れ

図 6 にも示したように，吹き溜まりが生じるような 屋根の風下側には得てして雪庇が形成される。冬山登 山をする人にとっては稜線の風下側の雪庇は命の危険 に直結する要注意事象だが，建物周りの雪庇も，その 大きさによっては直下を歩く人を傷つける可能性があ り，注意しなければならない。パラペットの笠木に急 勾配を付け，雪庇を形成しにくく寸る対策が取られる こともある。勾配屋根の軒先に形成された雪庇やつら らがクリープで垂れ下がると，巻き垂れを形成するこ とがある (図 8 参照)。空ガラスを破壊する原因となる ので，除去する必要がある。ただし，不用意な作業は 却って危険なので，慎重に行わなければならない。 


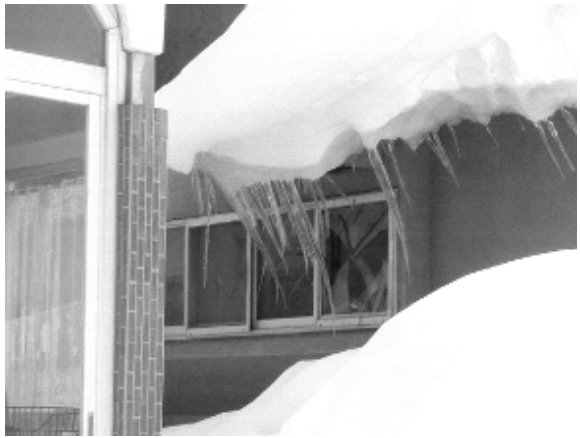

図 8 巻き垂れの例 7)

\section{3 着雪}

a) 送電施設への着雪

暴風雪時の雪の含水率や結晶構造によっては送電線 や送電鉄塔に筒状に雪が着雪し, 最悪の場合は送電線 が切れたり, 鉄塔が倒壊したりするなどの重着雪被害 が発生することがある。特に, 送電線の向きが変わる 点に位置する鉄塔には, 面外方向に引き倒すような力 として作用寸るので, 転倒被害が出や寸い。この原因 となる重着雪の防止策として, 導線に「難着雪リング」 を装着し，筒状に覆う前に落雪を促寸対策が取られて いる(図9, 図 10 参照)。図 10 では, 小さいのでわか りづらいが, 導線に $30 \mathrm{~cm}$ 間隔程度でポツポツと黒い 点が付いているのが確認できる。

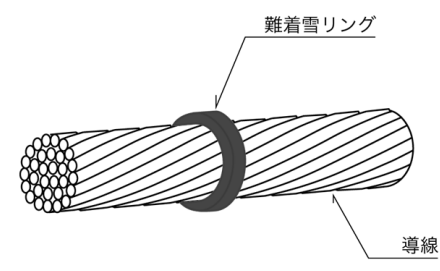

図 9 難着雪リングの概念図

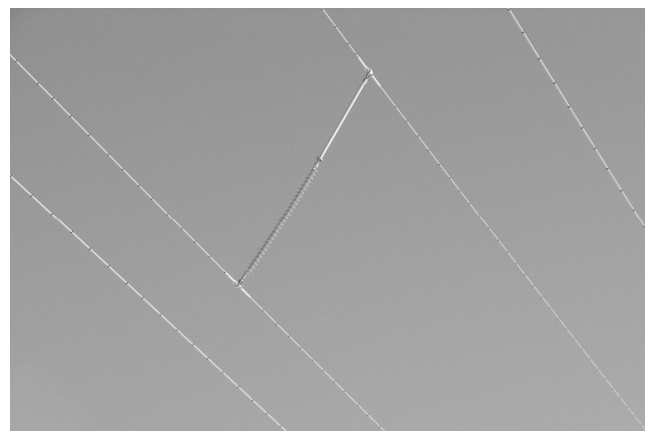

図 10 難着雪リングと相間スペーサの装着例
なお，図 10 で一番存在感のある導線間の突っ張り 棒のようなものは，相間スペーサであり，暴風雪時に 導線が暴れて (ギャロッピング), 接触・停電すること を防止するためのものである。

これらの他に，暴風雪により送電設備に影響を及ぼ す災害として，塩雪害がある。これは，導電性の高い 塩水成分が暴風雪で海から運ばれて, 碍子に着雪し, 絶縁が保たれなくなってしまうことで発生する。塩雪 害に強い碍子の形状や材質などに関寸る研究や対策が 行われている。

\section{b) 建物への着雪}

暴風雪の場合, 当然ながら建物にも着雪は発生する。 戸建住宅の場合，壁への着雪が問題になることは少な いが，高層建物の場合，着雪していた雪が部分的に融 解して落雪した場合，下を歩行している人を傷つける 可能性がある。最近, 温熱環境への配慮から高層建物

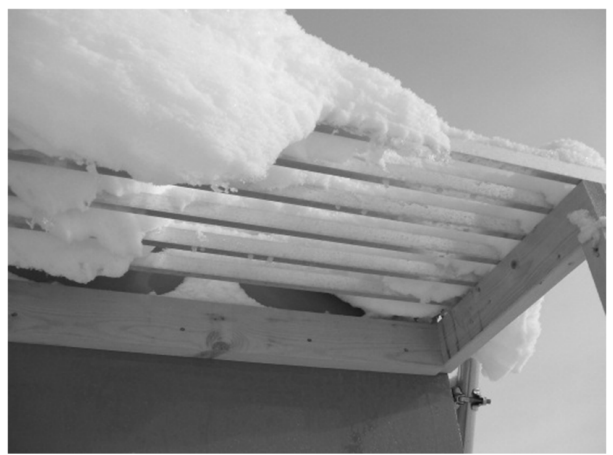

図 11 水平ルーバーへの冠雪の状況 ${ }^{7)}$

でもルーバーが用いられることがあるが，水平ルーバ 一はなめらかな壁面に比較して着雪，冠雪の可能性が 高く (図 11 参照), その計画には細心の注意が必要で ある。また，超高層建物の場合は地上では雨でも最上 層では雪となる場合もある ${ }^{8)}$

\section{3。まとめ}

以上，暴風雪によるいろいろな災害を概観し，具体 的な対策が示されているものについてはその代表例を 紹介した。吹き溜まりや着雪現象はその現象が生じた 際の風向に左右されるので, 常に同じ現象が再現され るわけではないことが対策を難しくしている。更なる 実例の蓄積と, CFD などによる解析的な研究と, 両面 からの探究が求められる。 
参考文献

1) 例えば, 朝日新聞, 2013 年 3 月 4 日朝刊

2) 土木研究所寒地土木研究所, 北の道ナビ (峠情報) http://northern-road.jp/navi/ (2017 年 5 月 8 日閲覧)

3）国土交通省，国が管理する一般国道及び高速自動車 国道の維持管理基準（案）, (2013.4), http://www.mlit.go.jp/road/ir/ir-council/pdf/iji1_1.pdf

4) 鈴木 修，JR 東日本における雪対策の現状と近年の 技術開発，日本雪工学会誌，Vol.32，No.2, pp.74-78，
(2016.4)

5) 鉄道林研究会, 鉄道林一 その歴史と管理技術〜, 交 通新聞社, 296pp., (2015.12)

6) 日本建築学会, 雪と建築, 技報堂出版, 113pp., (2010.8)

7) 日本建築学会, 建築物荷重指針・同解説 (2015), 日 本建築学会, (2015.2)

8) 日本建築学会, 建築物荷重指針を活か寸設計資料 1, 日本建築学会, (2016.2) 